\title{
THE IMPACT OF COSO CONTROL COMPONENTS ON INTERNAL CONTROL EFFECTIVENESS: AN INTERNAL AUDIT PERSPECTIVE
}

\author{
Houdini Fourie+ \\ Nelson Mandela Metropolotan University \\ Houdini.fourie@nmmu.ac.za \\ Christo Ackermann" \\ University of Johannesburg \\ cackermann@uj.ac.za
}

Received: September 2012

Accepted: January 2013

\begin{abstract}
Boards of directors have the ultimate responsibility for governance - including internal control - in their organisations. Management is tasked with the design, implementation and maintenance of internal control systems. Internal auditors play a key role in independently evaluating these controls, acting as agents on behalf of the board of directors in order to mitigate the possibility of management not acting in the best interest of the organization, leaving gaps in the internal control system, and, in some instances, doing so in order to enable unlawful personal gain. The Committee of Sponsoring Organisations' Integrated Framework for Internal Control (hereafter referred to as the COSO framework) is used as a recognised framework, which, if implemented, could result in an effective internal control system and served as the basis for the design of the research instrument of the research. The questionnaire was distributed to internal audit practitioners. Responses were obtained from 31 participants from the Eastern Cape and Western Cape regions in South Africa. The majority of the participants provide internal audit services to the local government sphere of the South African government. This article identifies which characteristics should exist in an organization's control system that, in the opinion of internal auditors, improve the effectiveness of the internal control system. This study concludes that internal auditors are of the opinion that control characteristics as outlined in the COSO framework for 'risk assessment', 'information and communication', 'control activities' and 'monitoring' components of internal control, do contribute to an effective internal control system.
\end{abstract}

Keywords

Control activities, control elements, COSO control framework, internal control, information and communication, monitoring, risk assessment, internal control effectiveness.

+Mr Houdini Fourie is a Senior Lecturer in the School of Accounting, Nelson Mandela Metropolitan University, Port Elizabeth, South Africa.

${ }^{\#}$ Mr Christo Ackermann is a senior lecturer in the Department of Commercial Accounting, University of Johannesburg, South Africa. 


\section{INTRODUCTION}

Incidents such as the collapse of Enron and WorldCom, caused investors, in an attempt to reduce the risk of losing funds, to be more wary of which markets they invested in (Berk \& Mehri, 2002; Bierstaker, Brody \& Pacini, 2006; Petra \& Loukatos, 2009). Scandals such as these are attributable to a weak internal control system (Skinner \& Spira, 2003). It is argued that having a strong internal control system is one of the best ways to deter fraud (D'Aquila, 1998; Hemraj, 2004; Holtfreter, 2005; Bierstaker et al., 2006; IIA, 2009). Boards of directors have responsibility over internal control and must timeously communicate to stakeholders such as investors any breakdowns in internal control that could impact investors' decisions (Hassabelnaby, Said \& Wolfe, 2007; loD, 2009; Barac \& Plant, 2010). The board appoints the audit committee to oversee, among other things, internal financial control. For audit committees to execute their duty effectively, they must have a good working relationship with the internal auditors and thus rely on their work (IoD, 2009).

Line management should implement controls and it is these controls that should be tested by the internal audit activity (IAA) (Hillison, Pacini \& Sinason, 1999; IIA, 2005; Philmore \& Howard, 2005; Petra et al., 2009). As a result of the increased responsibilities recommended by the King III report and other pronouncements on corporate governance directed at organisations, it is important that the controls implemented by management assist in ensuring that the objectives of 'reliable financial reporting', 'efficiency and effectiveness of operations', 'compliance with laws and regulations' and 'safeguarding of assets' are met (Van Wyk, 2010). The definition of internal auditing states that internal auditors play a key role in an organization's risk management, internal control and governance processes, which are key functions of boards of directors; hence internal auditors are in the best position to assist the audit committee and the board in the execution of their corporate governance responsibility, acting as the "eyes and ears" of the audit committee (Adams, 1994; Van Wyk, 2010).

\section{RESEARCH PROBLEM AND METHOD}

The primary objective of this research is to investigate how internal auditors perceive the importance and effect of the 'risk assessment', 'information and communication', 'control activities' and 'monitoring' components of the COSO control framework on the effectiveness of internal control systems of their organisations. The scientific information in this regard would be useful, as although it is a known fact that the COSO Control framework is the recommended control framework, all organisations have not yet fully implemented or integrated it with their internal control systems (Moeller, 2007) - possibly because they do not believe that it would improve the effectiveness of the internal control system of their organisations. Finding an answer to the research question below could prove that the incorporation of the COSO control framework elements does contribute to improving the effectiveness of internal control systems in the Eastern Cape and Western Cape local government authorities (municipalities) of the South African public sector. Improving the effectiveness of the internal control systems of municipalities could result in improved financial management.

The research question of this article is thus:

Do internal auditors perceive the incorporation of the elements of COSO's risk assessment; information and communication; control activities; and monitoring components in the design of 
a system of internal control as being effective in contributing to an improved internal control system for their organisations?

The data for this article was collected by means of a self-administered web-based questionnaire (refer Annexure A).

A snowball sampling process was followed. As a consequence of this sampling method the majority of the participants were those who provide outsourced internal audit services to municipalities in the Eastern and Western Cape regions - the local government sphere of the South African public sector. The questionnaire was distributed via electronic mail to two internal auditors in audit firms who were requested to forward the universal resource locator (URL) to other internal auditors in their partner firms.

These qualifications of the participants (mainly chartered accountants) ensured that competent internal auditors with sufficient experience in the evaluation and assessment of internal control systems from in-house and outsourced Internal Audit Activities (IAAs) were included in the sample of the study. Participants of the desired population were identified and they were relied upon to distribute the URL until an acceptable sample was obtained to perform basic statistical calculations. Laerd Dissertation (2012) states that this is typical and acceptable practice of snowball sampling techniques to identify a unit of the desired population and "using these units to find further units and so on until the sample size is met", which is the assertion on which the sampling technique of this article is based. After regular follow-up emails sent to the participants, the URL was disabled and 31 responses were obtained. This sample size was regarded as sufficient to perform basic statistical calculations (Gleim, 2009). The data was exported to an excel sheet for statistical analysis.

The questionnaire was divided into the five internal control components according to the COSO framework. This article focuses on only those responses obtained in respect of the components outlined in the research question. Each question contains statements relevant to a particular internal control characteristic of the relevant control component. Participants were requested to indicate whether their organization has implemented certain control characteristics. A 'not true' response indicates that the control characteristic has not been implemented. If the specific control characteristic has been implemented participants were required to rate the perceived effectiveness of the control characteristic on a Likert scale from two to five, with two being 'not effective', three 'effective', four 'very effective' and five 'extremely effective' in increasing (improving) the effectiveness of the internal control system.

Likert scales are effective when an overall measurement is to be obtained on a certain topic or contributing factors (Vanek, 2012). This argument is applicable to this article, as participants were requested to indicate their perception on whether, in their opinion, the given options are contributing to an improved internal control system in their organisations. Losby and Wetmore (2012) posit that Likert scales are also effective when a researcher wants to obtain the attitudes or perceptions of participants on a specific statement, which were also applicable to this research.

The questionnaires were distributed to both in-house and outsourced internal auditors of organisations in the target population. 


\section{LIMITATIONS}

In respect of the population of the research, this article is limited to internal auditors in the Eastern Cape and Western Cape regions of South Africa. A further limitation is that this article does not test the effectiveness of control systems of organisations but only the perceived effect and importance of the relevant control of the COSO framework and those stated by the American Institute of Certified Public Accountants (AICPA) for the internal control system. Other control frameworks such as the Criteria of Control model ( $\left.\mathrm{CoC}_{0}\right)$, the Control Objectives for Information and related Technology model (COBIT) and the COSO Enterprise Risk Management (ERM) framework were not considered in the questionnaire. These frameworks were excluded, as the CoCo model consists of only 20 control criteria (International Federation of Accountants, 2006); COBIT focuses on information technology (IT) controls specifically designed for the IT environment; and the COSO ERM framework extends to the broader area of enterprise risk management. Further research could be directed at obtaining the views of internal auditors with regard to the COSO control components not included in this article and perceptions of CAEs in respect of the effectiveness of an internal control system based on COSO control elements.

As a result of the large amount of information obtained under the control environment component, it was not included as part of this article. A further article on the perceptions of internal auditors as to the impact of the control environment component on the effectiveness of the internal control system is being considered.

\section{VALUE OF THE RESEARCH}

The information obtained on the perceptions of internal auditors on the contribution of COSO control components on the effectiveness of internal control systems, with specific reference to the components outlined in the research question, is useful to the IIA when considering guidance pronouncements on technical matters. Internal audit educators could benefit from this research in the alignment of the curricula of formal internal audit programme qualifications. Management, as the owners of control systems, can benefit from the results of this research by realizing the importance of the degree of influence that components of internal control, if implemented, have on the effectiveness of the internal control system in the organization resulting in improved financial management of local government authorities in the Eastern and Western Cape regions of South Africa.

\section{LITERATURE REVIEW}

Published results from previous studies indicate the effectiveness of fraud prevention and detection methods (Bierstaker et al., 2006; Moyes, Lin, Landry \& Vicdan, 2006). In a further study the perception of management was obtained in respect of the effectiveness of the internal control system in regard to strategy, control activities and monitoring activities, and how a combination of these could contribute to the effectiveness of internal control systems (Agbejule \& Jokipii, 2009). However, these studies did not include the COSO framework control elements or its perceived effectiveness from an internal auditor perspective. 


\subsection{The changing role of internal auditors}

Davis and Lumkomnik (2010) state that internal auditors, when conducting internal audit engagements, should keep the best interest of the investor in mind. This means that when they are evaluating internal control effectiveness internal auditors must be objective and independent in order to provide investors with reasonable assurance in respect of the integrity and reliability of financial and other information. Internal auditors are part of a combined assurance model - together with the board, management, the audit committee and external auditors. Obtaining independent views on the effectiveness and integrity of the internal control system could increase confidence in the work performed, not only by internal auditors, but also by management, which bears the ultimate responsibility for the control activities, boosting investors' confidence (Baker, 2010; Blackmore, 2010). These assertions emphasise the need to study internal auditors' perceptions in respect of the contribution that control elements could have on the effectiveness of their organization's internal control systems.

Rezaee (2010) asserts that internal auditors have a continuously changing role - one that is important to the efficiency and effectiveness of an organization's internal control system. The importance of the role is emphasised through the internal auditor's independence from operations, which enables him or her to express objective opinions on the adequacy and effectiveness of internal control (IIA, 2009). The role of the internal auditor has changed in that internal auditors have to assist the board and the audit committee in reporting to shareholders on the effectiveness and efficiency of internal control activities, risk management and governance processes. This means that they have a consulting role in addition to the normal assurance role (Sawyer, Dittenhofer \& Scheiner, 2003; IIA, 2009; Rezaee, 2010; IIA, 2010a; IIA, 2010b).

The above discussion supports the research objective of this article. Expanded roles and more stringent governance codes and pronouncements suggest that internal auditors express their opinion on which control characteristics could contribute to the effectiveness of an organization's internal control system.

\subsection{The COSO framework}

The COSO control framework highlights the objectives of internal control systems, namely: "efficient and effective operations; reliable financial reporting; compliance with laws and regulations and safeguarding of assets" (Applegate \& Wills, 1999). In addition, five essential components are outlined by the COSO control framework, namely (Applegate et al., 1999):

- The control environment;

- Risk assessment;

- Control activities;

- Information and communication; and

- monitoring

In addition, the COSO framework suggests that the Chief Executive Officer (CEO) has ownership of the internal control system (Baker, 2009). Part of this ownership (or responsibility) is to create a top-down environment where internal control is regarded as critical to the success of the organization; this culture should then filter down the organizational hierarchy, impacting the way employees regard internal control. The 'control environment' is the first component and forms the basis of the COSO framework (Vanasco, Skousen \& Verschoor, 1995; Rezaee, 1995; 
Herremans, 1997; Baker, 2009). The COSO framework stresses the importance of establishing an environment which makes managers aware of and sensitive to the risks in their business units; they should then monitor the controls designed to mitigate risks and take timely corrective action if control activities are not working as intended (Baker, 2009). The COSO framework emphasises the importance of internal control activities and provides a basis for entities, in an attempt to ensure responsible corporate governance and reliable financial reporting, to maintain due care of their systems of internal control (Vanasco et al., 1995).

\subsection{Control attributes of the COSO framework}

The American Institute of Certified Public Accountants (AICPA) has created a comprehensive tool for audit committees to obtain reasonable assurance on whether controls under the five interrelated COSO components (control environment, risk assessments, information and communication, control activities and monitoring) are operating as intended. AICPA (2005) and COSO (1994) provide a list of attributes that could contribute towards a more effective internal control system. The following section provides a detailed discussion of these attributes.

\subsection{Control components}

The activities or measures outlined in the following sections, if implemented in an organization, could contribute to the effectiveness of the internal control system (COSO, 1994; AICPA, 2005). In support of the objective of this study, internal auditor participants were requested to indicate whether the control characteristics listed below are, in their opinion, contributing towards an effective internal control system (internal auditor perspective) for each of the components listed in the research question.

\subsubsection{Risk assessment}

The management of organisations should consider all risks, internal and external, that could mean that objectives are not achieved. Furthermore, risks that financial statements could be materially misstated should also be considered. To his end, management should estimate the significance of risk, determine the likelihood of risk occurring and determine the impact or consequence of the identified risks on the organization. It is important for management to identify control activities to mitigate the identified risks (AICPA, 2005; COSO, 1994).

Spencer Pickett (2005) states that organisations should have a process of identifying and assessing risk. This is a very important aspect of the control system, because of risk is not identified no foundation exists for knowing how the risks should be managed via implementation of control activities (Spencer Pickett, 2005; Coetzee, du Bruyn, Fourie \& Plant, 2010).

\subsubsection{Information and communication}

A process should be in place to identify relevant information from external sources which could have relevance to the organization. Procedures should be established to ensure that reporting deadlines are met and that relevant information is communicated in a timely manner to the appropriate level and in a format that will facilitate easy analysis of the data. New information needs should be identified and addressed.

A process should exist to capture and register complaints and/or errors to prevent it from happening again. In addition, procedures should be in place explaining to employees what they 
should do if they suspect any wrongdoing and who the relevant persons are to whom this should be communicated. The accounting system should be divided into different classes of transactions to make reporting easier and be set up in such a way as to ensure completeness and accuracy of records; and to prevent any duplicate recording (AICPA, 2005; COSO, 1994).

The information and communication component of internal control emphasise that relevant control, and other related, information should be identified and communicated to relevant parties within the organization at the right time and format to enable the use of the information (Spencer Pickett, 2005; Coetzee et al., 2010; Jackson \& Stent, 2012). Furthermore, it is important that all processes within an organization should be captured in official policy and procedure manuals which should be distributed to all staff so that they are aware of their responsibilities and how their responsibilities affect those of others within the organization (Spencer Pickett, 2005; Coetzee et al., 2010; Jackson et al., 2012).

\subsubsection{Control activities}

All policies and procedures should be in the form of written manuals, and the procedures for each activity in the organization should be applied accordingly. These established policies and procedures should be reviewed and updated on a regular basis. Supervisory staff should review the functioning of controls with reference to the relevant procedure. Any deviations from the procedure that are identified should be communicated to relevant parties and corrected timeously. Custody over assets should be separate from the accounting function. The responsibility for operational and record-keeping should be separate from each other. Physical control over assets should exist: for example, good gate control. All policies and procedures should be subject to review by an independent party such as the IAA (AICPA, 2005; COSO, 1994).

Control activities are defined as the actions executed by role players to manage risk (Spencer Pickett, 2005; Coetzee et al., 2010; Jackson et al., 2012). Various control activities exist such as segregation of incompatible functions, proper authorization of transactions, independent review of performance, isolation of responsibilities, proper access control (physical and logical), comparisons and reconciliations and good document design (Spencer Pickett, 2005; Coetzee et al., 2010; Jackson et al., 2012).

\subsubsection{Monitoring}

Staff should sign off when key activities such as performing bank reconciliations are performed. Employees should be made aware that the onus is on them to communicate any deficiencies in the prescribed controls. In addition, organisations could use customers to identify certain weaknesses in the control system by, for example, examining customer complaints and conducting customer satisfaction surveys. Management should take corrective action on recommendations made by the IAA. Furthermore, the IAA should do follow-up audits to ensure that management has implemented agreed changes. Organisations should rely on the IAA for effective monitoring of controls if such an activity exists. Management of organisations should use exception reports to identify deviations from policies and procedures and use reports generated by operating staff as a tool in identifying deviations from and non-compliance with policies and procedures (AICPA, 2005; COSO, 1994).

Spencer Pickett (2005) emphasises the importance of the monitoring component of internal control by placing the monitoring component "on top" of the other four components of internal control. This is due to the fact that for controls to be working effectively, they need to be 
monitored on a regular basis (Coetzee et al., 2010). Organisations operate in an ever-changing environment, which means that the risks facing organisations constantly change, hence the controls could become obsolete; therefore monitoring these conditions is important to ensure that business objectives are achieved by ensuring controls are relevant and working effectively (Spencer Pickett, 2005; Coetzee et al., 2010; Jackson et al., 2012).

\subsection{Areas for further research}

Further research should be conducted in respect of the COSO ERM framework, which includes elements of COSO's integrated internal control framework, incorporating a broader risk management approach.

Secondly, the perceptions of Chief Audit Executives (CAEs) could be obtained on the effectiveness of the internal control system based on control elements as outlined in the COSO framework and the COSO ERM framework. The following section provides detailed discussion of the findings of the research and provides recommendations in respect of the findings.

\section{FINDINGS AND RECOMMENDATIONS}

The findings from the responses to the research instrument are discussed in the following sections.

\subsection{Professional information on participants}

Most of the participants are Chartered Accountants (CAs) (61\%) followed by Certified Internal Auditors (19\%). Some of the participants indicated that they have no professional qualifications (13\%), but they do have sufficient internal control-related experience. More than $70 \%$ of the participants indicated that they have more than five years of internal audit experience. Seven participants who hold the CA designation did not have internal audit specific experience. Due to the stringent training and education requirements in becoming a $C A$, it can be argued that these participants had sufficient knowledge and expertise to contribute to the value of the study.

\subsection{A summary of participants' perceptions on which control characteristics could improve the effectiveness of an internal control system}

The tables in this section summarise the results of the research with respect to the different components of internal control as outlined in the research question of this study.

\subsubsection{Risk assessment}

TABLE 1 shows the results of the 'risk assessment' component of internal control. The table summarises good control characteristics which should form part of the risk assessment component of internal control. 
TABLE 1: Participants' perceptions of the impact of the COSO risk assessment component elements/characteristics on internal control effectiveness

\begin{tabular}{|c|c|c|c|c|c|}
\hline Controlelement/characteristic & 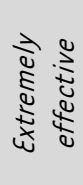 & 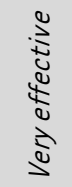 & 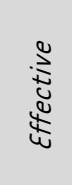 & 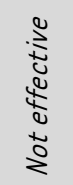 & 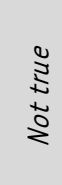 \\
\hline The organization considers risk from external sources & $10 \%$ & $35 \%$ & $39 \%$ & $16 \%$ & $0 \%$ \\
\hline The organization considers risks from internal sources & $6 \%$ & $19 \%$ & $52 \%$ & $19 \%$ & $3 \%$ \\
\hline $\begin{array}{l}\text { The risk of a misstatement of the financial statements is } \\
\text { considered, and steps are taken to mitigate that risk }\end{array}$ & $6 \%$ & $26 \%$ & $55 \%$ & $6 \%$ & $6 \%$ \\
\hline $\begin{array}{l}\text { The risks associated with foreign/offshore operations are } \\
\text { considered }\end{array}$ & $10 \%$ & $23 \%$ & $39 \%$ & $16 \%$ & $13 \%$ \\
\hline Management estimates the significance of risk & $3 \%$ & $26 \%$ & $58 \%$ & $13 \%$ & $0 \%$ \\
\hline Management assesses the likelihood of risk occurring & $3 \%$ & $23 \%$ & $58 \%$ & $16 \%$ & $0 \%$ \\
\hline Management assesses the impact of risk occurring & $3 \%$ & $26 \%$ & $55 \%$ & $16 \%$ & $0 \%$ \\
\hline $\begin{array}{l}\text { Management takes necessary action to manage risks } \\
\text { identified }\end{array}$ & $6 \%$ & $26 \%$ & $42 \%$ & $23 \%$ & $3 \%$ \\
\hline
\end{tabular}

Source: Statistical analysis

Most of the participants indicated that all the procedures listed under 'risk assessment' are 'effective'. This could be due to an increased awareness of the risk management process and the pressure exerted by boards and audit committees on internal auditors, as the strategic risk management process is considered to be one of the top five primary responsibilities of internal auditors (Cain, 2010). It is also considered to be a great challenge for audit committees in future (COSO, 2010; KPMG, 2010; Steffee, 2010). CEOs indicated that having better risk management practices is beneficial to organisations (Cain, 2010); hence, most participants perceived that the procedures under risk assessment are 'effective' in increasing the effectiveness of the internal control system. These responses could also be as a result of the events of the past decade that have led to organisations adopting a more focused risk management strategy, moving away from 'silo' risk managing (Aghili, 2010; Sobel, 2010).

\subsubsection{Information and communication}

TABLE 2 summarises the results of the information and communication component. The table outlines attributes which should form part of an organization's information and communication practices as defined by the COSO framework.

As can be observed from data point one, $6 \%$ responded that no process is in place to collect information from external sources that could have an impact on the organization and the financial reporting process. Where such a process does exist, respondents $(23 \%)$ indicated that this is 'not effective'. However, $48 \%$ responded 'effective', 19\% 'very effective' and just 3\% felt that this is 'extremely effective'. 
TABLE 2: Participants' perceptions of the impact of the COSO information and communication component elements/characteristics on internal control effectiveness

\begin{tabular}{|c|c|c|c|c|c|c|}
\hline $\begin{array}{l}\text { Data } \\
\text { point }\end{array}$ & Control element/characteristic & 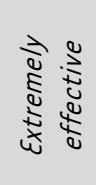 & 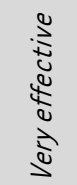 & 究 & 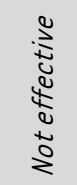 & 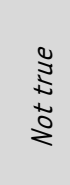 \\
\hline 1 & $\begin{array}{l}\text { A process is in place to collect information from } \\
\text { external sources that could have an impact on } \\
\text { the organization and the financial reporting } \\
\text { process }\end{array}$ & $3 \%$ & $19 \%$ & $48 \%$ & $23 \%$ & $6 \%$ \\
\hline 2 & $\begin{array}{l}\text { Milestones to achieve financial reporting } \\
\text { objectives are monitored to ensure that timing } \\
\text { deadlines are met }\end{array}$ & $10 \%$ & $13 \%$ & $61 \%$ & $6 \%$ & $10 \%$ \\
\hline 3 & $\begin{array}{l}\text { Necessary operational and financial information } \\
\text { is communicated to the right people in the } \\
\text { organization on a timely basis }\end{array}$ & $13 \%$ & $6 \%$ & $65 \%$ & $16 \%$ & $0 \%$ \\
\hline 4 & $\begin{array}{l}\text { Necessary operational information is } \\
\text { communicated to the right people in the } \\
\text { organization in a format that facilitates its use }\end{array}$ & $10 \%$ & $13 \%$ & $65 \%$ & $13 \%$ & $0 \%$ \\
\hline 5 & $\begin{array}{l}\text { Necessary financial information is } \\
\text { communicated to the right people in the } \\
\text { organization in a format that facilitates its use }\end{array}$ & $10 \%$ & $16 \%$ & $61 \%$ & $13 \%$ & $0 \%$ \\
\hline 6 & $\begin{array}{l}\text { A process is in place to respond to new } \\
\text { information needs in the organization on a } \\
\text { timely basis }\end{array}$ & $3 \%$ & $13 \%$ & $65 \%$ & $10 \%$ & $10 \%$ \\
\hline 7 & $\begin{array}{l}\text { There is a process in place to collect and } \\
\text { document complaints to analyse, determine } \\
\text { cause, and eliminate a problem from recurring in } \\
\text { the future }\end{array}$ & $7 \%$ & $17 \%$ & $55 \%$ & $14 \%$ & $7 \%$ \\
\hline 8 & $\begin{array}{l}\text { There is a process in place to collect and } \\
\text { document errors to analyse, determine cause, } \\
\text { and eliminate a problem from recurring in the } \\
\text { future }\end{array}$ & $6 \%$ & $6 \%$ & $61 \%$ & $23 \%$ & $3 \%$ \\
\hline 9 & $\begin{array}{l}\text { A process is established and communicated to } \\
\text { stakeholders about how to communicate } \\
\text { suspected instances of wrongdoing by the } \\
\text { organization }\end{array}$ & $3 \%$ & $10 \%$ & $48 \%$ & $26 \%$ & $13 \%$ \\
\hline 10 & $\begin{array}{l}\text { The accounting system consists of different } \\
\text { classes of transactions }\end{array}$ & $6 \%$ & $32 \%$ & $52 \%$ & $6 \%$ & $3 \%$ \\
\hline 11 & $\begin{array}{l}\text { The accounting system ensures completeness of } \\
\text { records }\end{array}$ & $6 \%$ & $23 \%$ & $48 \%$ & $19 \%$ & $3 \%$ \\
\hline
\end{tabular}




\begin{tabular}{|c|c|c|c|c|c|c|}
\hline $\begin{array}{l}\text { Data } \\
\text { point }\end{array}$ & Controlelement/characteristic & 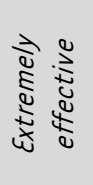 & 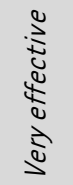 & 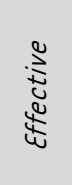 & 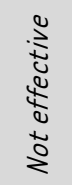 & 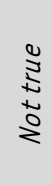 \\
\hline 12 & $\begin{array}{l}\text { The accounting system ensures accuracy of } \\
\text { records }\end{array}$ & $6 \%$ & $23 \%$ & $48 \%$ & $16 \%$ & $6 \%$ \\
\hline 13 & $\begin{array}{l}\text { The accounting system avoids duplicate } \\
\text { recording }\end{array}$ & $6 \%$ & $19 \%$ & $55 \%$ & $13 \%$ & $6 \%$ \\
\hline
\end{tabular}

Source: Statistical analysis

In data point two, $10 \%$ of respondents indicated that milestones for achieving financial reporting objectives are not monitored to ensure that timing deadlines are met. When these milestones are monitored, $6 \%$ of respondents indicated that this is 'not effective'. Of the other respondents, however, more than half, $61 \%$, maintained that this is 'effective', $13 \%$ felt this is 'very effective', but only $10 \%$ reported 'extremely effective'.

Data point three reveals that all respondents indicated that necessary operational and financial information is communicated to the right people in the organization on a timely basis; however, $16 \%$ perceive this as not being effective. On the other hand, more than half, $65 \%$, felt this is 'effective', $6 \%$ perceived this as 'very effective' and just $13 \%$ stated 'extremely effective'.

From the data in data point four, it can be seen that all respondents indicated that necessary operational information is communicated to the right people in the organization in a format that facilitates its use. However, $13 \%$ responded that this is 'not effective'. Nevertheless, more than half ( $65 \%)$ of the respondents perceived this to be 'effective'; $13 \%$ 'very effective' and $10 \%$ reported that this is 'extremely effective'.

It was determined in data point five that all respondents stated that necessary financial information is communicated to the right people in the organization in a format that facilitates its use. However, $13 \%$ indicated that this is 'not effective', more than half (61\%) perceive this as 'effective', while $16 \%$ reported 'very effective' and only $10 \%$ indicated 'extremely effective'.

In data point six, $10 \%$ of respondents indicated that there is no process in place to respond to new information needs in the organization on a timely basis. Where such a process does exist, $10 \%$ of respondents indicated that this is 'not effective'. However, more than half, $65 \%$, reported 'effective', $13 \%$ indicated 'very effective'; and only $3 \%$ of the respondents indicated that this is 'extremely effective'.

Data point seven reveals that $7 \%$ of respondents feel that no process is in place to collect and document complaints in order to analyse, determine cause and stop a problem from recurring in the future. Where such a process exists, $14 \%$ indicated that this is 'not effective'. More than half $(55 \%)$, however, responded this is 'effective', $17 \%$ responded 'very effective' and $7 \%$ 'extremely effective'.

For data point eight, $3 \%$ of respondents indicated that no process is in place to collect and document errors in order to analyse, determine cause and stop a problem from recurring in the future. Where such a process does exist, $23 \%$ indicated that this is 'not effective'; more than 
half, $61 \%$, responded 'effective', and $6 \%$ indicated this is 'very effective' and 'extremely effective'.

For data point nine, $13 \%$ of respondents indicated that no process has been established or communicated to stakeholders about how to communicate suspected instances of wrongdoing by the company. Where such a process has been established and communicated, $26 \%$ of the respondents perceive this as 'not effective', $48 \%$ as 'effective', $10 \%$ as 'very effective' and only $3 \%$ indicated that this is 'extremely effective'.

Feedback from the respondents, shown in data point ten, found that $3 \%$ of the respondents indicated that the accounting system does not comprise of different classes of transactions. Where the accounting system is divided into such classes, $6 \%$ perceive this as 'ineffective', more than half ( $52 \%$ ) indicated 'effective', and $32 \%$ reported 'very effective', while only $6 \%$ maintain this is 'extremely effective'.

In data point eleven, $3 \%$ of respondents stated that the accounting in their organization system does not ensure completeness of records. Where the accounting system does ensure this, $19 \%$ perceive this is not being effective, $48 \%$ responded 'effective', while $23 \%$ deem it to be 'very effective'. Only $6 \%$ felt that this is 'extremely effective'.

For data point twelve, $6 \%$ of the respondents stated that the accounting system in their organization does not ensure the accuracy of records. Where the accounting system does ensure accuracy, $16 \%$ of the sample indicated that this is 'not effective', $48 \%$ 'effective', while $23 \%$ of the sample said 'very effective'. Only $6 \%$ of the respondents chose the 'extremely effective' option.

Data point thirteen reveals that $6 \%$ of accounting systems reported on by respondents do not avoid duplicate recording. Where the system does avoid duplicate recording, $13 \%$ of respondents perceive this is 'not effective'; more than half, $55 \%$, responded that this is 'effective', while $19 \%$ reported 'very effective'. Only $6 \%$ felt that this is 'extremely effective'.

\subsubsection{Control activities}

TABLE 3 summarises the results of the control activity component of the COSO control framework. The table highlights specific control activities which should form part of an organization's attempt to mitigate risk such as segregation of duties, custody controls and independent review of performance.

TABLE 3: Participants' perception on the impact of the COSO control activities component elements/characteristics on internal control effectiveness

\begin{tabular}{|c|c|c|c|c|c|c|}
\hline $\begin{array}{l}\text { Data } \\
\text { point }\end{array}$ & Controlelement/characteristic & 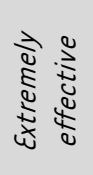 & 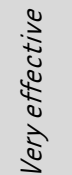 & $\frac{2}{\Delta}$ & 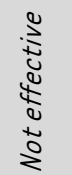 & 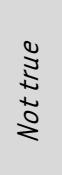 \\
\hline 1 & $\begin{array}{l}\text { The organization has a process in place to ensure } \\
\text { that controls as described in policy and procedure }\end{array}$ & $3 \%$ & $16 \%$ & $52 \%$ & $26 \%$ & $3 \%$ \\
\hline
\end{tabular}
applied 


\begin{tabular}{|c|c|c|c|c|c|c|}
\hline $\begin{array}{l}\text { Data } \\
\text { point }\end{array}$ & Control element/characteristic & 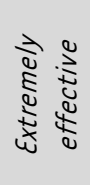 & 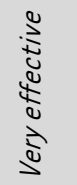 & 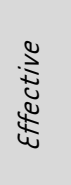 & 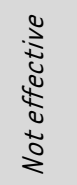 & 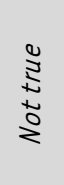 \\
\hline 2 & $\begin{array}{l}\text { Policy and procedure manuals document all } \\
\text { important controls }\end{array}$ & $6 \%$ & $23 \%$ & $42 \%$ & $26 \%$ & $3 \%$ \\
\hline 3 & $\begin{array}{l}\text { Policies and procedures are reviewed and updated } \\
\text { on a regular basis }\end{array}$ & $3 \%$ & $17 \%$ & $50 \%$ & $27 \%$ & $3 \%$ \\
\hline 4 & $\begin{array}{l}\text { Supervisory personnel review the functioning of } \\
\text { controls }\end{array}$ & $3 \%$ & $23 \%$ & $45 \%$ & $23 \%$ & $6 \%$ \\
\hline 5 & $\begin{array}{l}\text { Timely and appropriate follow-up action is taken } \\
\text { on exception reports }\end{array}$ & $6 \%$ & $26 \%$ & $48 \%$ & $16 \%$ & $3 \%$ \\
\hline 6 & Custody over assets is separate from accounting & $6 \%$ & $29 \%$ & $39 \%$ & $19 \%$ & $6 \%$ \\
\hline 7 & $\begin{array}{l}\text { Operational responsibility and record-keeping } \\
\text { responsibility are separated }\end{array}$ & $6 \%$ & $29 \%$ & $48 \%$ & $13 \%$ & $3 \%$ \\
\hline 8 & Physical control over assets exists & $3 \%$ & $23 \%$ & $55 \%$ & $19 \%$ & $0 \%$ \\
\hline 9 & There are independent checks on performance & $6 \%$ & $26 \%$ & $48 \%$ & $10 \%$ & $10 \%$ \\
\hline
\end{tabular}

\section{Source: Statistical analysis}

In respect of data point one, only $3 \%$ of respondents indicated that their organisations do not have a process in place to ensure that controls as described in policy and procedure manuals are applied as they are meant to be applied. Where controls are applied, $26 \%$ of respondents indicated that this 'not effective', more than half, $52 \%$, responded 'effective', $16 \%$ 'very effective', while only $3 \%$ chose 'extremely effective'.

Data point two reveals that $3 \%$ of organisations' policy and procedure manuals do not document all the relevant policies and procedures. Where organisations do document all relevant policies and procedures, $26 \%$ of the respondents indicated that they are 'not effective', $42 \%$ reported this as 'effective', $23 \%$ 'very effective' and only $6 \%$ 'extremely effective'.

It was found in data point three that $3 \%$ of the respondents do not review and update policy and procedures on a regular basis. Where such documents are reviewed and updated regularly, $27 \%$ of the respondents perceive this as not being 'effective', half of the respondents (50\%) state that this is 'effective', $17 \%$ feel that this is 'very effective' and only $3 \%$ of the respondents maintain that this is 'extremely effective'.

The respondents' feedback in data point four shows that $6 \%$ indicated that supervisory personnel do not review the functioning of controls. Where they do review this, $23 \%$ of the respondents perceive this is 'not effective', $45 \%$ 'effective', $23 \%$ 'very effective' and only $3 \%$ indicate this is 'extremely effective'.

The results show that, in data point five, $3 \%$ of the respondents do not carry out timely and appropriate follow-up action on exception reports. When they do, $16 \%$ of the sample indicated this is 'not effective', $48 \%$ perceives this as 'effective', 26\% 'very effective' and only $6 \%$ responded 'extremely effective'. 
For data point six, $6 \%$ of the respondents indicated that custody over assets is not separate from accounting. Where custody over assets is separate, $19 \%$ indicated that this is 'not effective', $39 \%$ reported 'effective', $29 \%$ 'very effective' and only $6 \%$ perceives this as being 'extremely effective'.

In data point seven, $3 \%$ of the sample indicated that operational and record-keeping responsibility is not separate. Where this responsibility is separated, $13 \%$ perceive this is 'not effective', $48 \%$ indicated 'effective', $29 \%$ 'very effective' and just $6 \%$ maintained this is 'extremely effective'.

When considering TABLE 3 , for data point eight, all the respondents stated that physical control over assets exists; however, $19 \%$ reported this control is 'not effective', more than half, $55 \%$, reported this is 'effective', $23 \%$ 'very effective' and $3 \%$ of the respondents chose the 'extremely effective' option.

Lastly, according to the results for data point nine, $10 \%$ of respondents indicated that no independent checks on performance are executed. Where such checks are in place, $10 \%$ of the respondents indicated that such checks are 'not effective', $48 \%$ indicated that they are 'effective', $26 \%$ stated they are 'very effective' and $6 \%$ indicated they are 'extremely effective'.

\subsubsection{Monitoring}

TABLE 4 summarises the results of the monitoring component for the COSO control framework. The table shows which types of monitoring activities should be undertaken by organisations, as defined by the COSO framework, which could aid in ensuring that controls are up to date and working as intended. These include, continuous monitoring, using exception reports and using the internal audit department as a monitoring tool.

TABLE 4: Participants' perception on the impact of the COSO monitoring component elements/characteristics on internal control effectiveness

\begin{tabular}{|c|c|c|c|c|c|c|}
\hline $\begin{array}{l}\text { Data } \\
\text { point }\end{array}$ & Control element/characteristic & 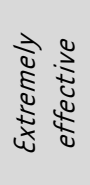 & 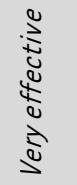 & 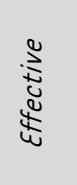 & 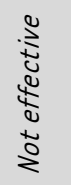 & 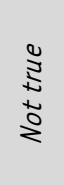 \\
\hline 1 & $\begin{array}{l}\text { Personnel are required to sign off, indicating their } \\
\text { performance of critical control activities such as } \\
\text { performing reconciliations }\end{array}$ & $6 \%$ & $16 \%$ & $58 \%$ & $10 \%$ & $10 \%$ \\
\hline 2 & $\begin{array}{l}\text { Employees understand their obligation to } \\
\text { communicate observed weaknesses in design with } \\
\text { the internal control structure of the organization } \\
\text { to the appropriate supervisory personnel }\end{array}$ & $3 \%$ & $10 \%$ & $48 \%$ & $29 \%$ & $10 \%$ \\
\hline 3 & $\begin{array}{l}\text { Employees understand their obligation to } \\
\text { communicate observed weaknesses in compliance } \\
\text { with the internal control structure of the } \\
\text { organization to the appropriate management } \\
\text { personnel }\end{array}$ & $3 \%$ & $10 \%$ & $45 \%$ & $32 \%$ & $10 \%$ \\
\hline
\end{tabular}




\begin{tabular}{|c|c|c|c|c|c|c|}
\hline $\begin{array}{l}\text { Data } \\
\text { point }\end{array}$ & Control element/characteristic & 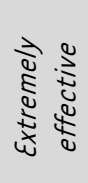 & $\begin{array}{l}0 \\
0 \\
0 \\
0 \\
0 \\
0 \\
0 \\
0 \\
0\end{array}$ & 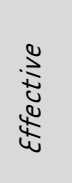 & 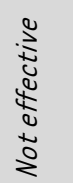 & 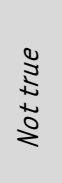 \\
\hline 4 & $\begin{array}{l}\text { The organization relies on customer complaints to } \\
\text { identify certain control weaknesses }\end{array}$ & $3 \%$ & $13 \%$ & $45 \%$ & $16 \%$ & $23 \%$ \\
\hline 5 & $\begin{array}{l}\text { There is follow-up on recommendations from the } \\
\text { internal auditors for improvements to the internal } \\
\text { control system }\end{array}$ & $6 \%$ & $13 \%$ & $55 \%$ & $19 \%$ & $6 \%$ \\
\hline 6 & $\begin{array}{l}\text { The organization relies on the internal audit } \\
\text { department for effective monitoring of controls }\end{array}$ & $3 \%$ & $16 \%$ & $61 \%$ & $3 \%$ & $16 \%$ \\
\hline 7 & $\begin{array}{l}\text { The organization relies on exception reports to } \\
\text { monitor effectiveness of controls }\end{array}$ & $3 \%$ & $16 \%$ & $61 \%$ & $10 \%$ & $10 \%$ \\
\hline 8 & $\begin{array}{l}\text { The organization relies on operating personnel } \\
\text { generated reports to monitor controls }\end{array}$ & $3 \%$ & $13 \%$ & $58 \%$ & $16 \%$ & $10 \%$ \\
\hline
\end{tabular}

Source: Statistical analysis

In TABLE 4 results for data point one reveals that $10 \%$ of the respondents indicated that personnel do not need to sign off, thus indicating that they have performed critical control activities such as reconciliations. Where personnel do sign off, $10 \%$ indicated this is 'not effective', more than half, $58 \%$, reported 'effective', while $16 \%$ responded this is 'very effective'. Only $6 \%$ of the respondents maintained this is 'extremely effective'.

Data point two shows that $10 \%$ of the respondents indicated that employees do not understand their obligation to communicate observed weaknesses in design in terms of the internal control system of the organization to appropriate supervisory personnel. Where employees do report such weaknesses, $29 \%$ perceive this is 'not effective', $48 \%$ 'effective', $10 \%$ 'very effective', and only $3 \%$ reported 'extremely effective'.

In data point three, $10 \%$ of respondents indicated that employees do not understand their obligation to communicate observed weaknesses in compliance with the internal control system of the organization to the appropriate supervisory personnel. Where employees do report such weaknesses, $32 \%$ indicated 'not effective', $45 \%$ 'effective', $10 \%$ 'very effective' and only $3 \%$ responded that this is 'extremely effective'.

It was determined in data point four that $23 \%$ of the respondents indicated that their organisations do not rely on customer complaints to identify certain control weaknesses. Where they do rely on customer complaints, $16 \%$ indicated this is 'not effective', $45 \%$ 'effective', and $13 \%$ 'very effective', while $3 \%$ responded 'extremely effective'.

Feedback from respondents shows, in data point five, that $6 \%$ felt that no follow-up on recommendations from the internal audit department is performed. Where follow-up is done, $19 \%$ of the respondents perceive this as 'not effective', more than half, $55 \%$, agreed this is 'effective', and $13 \%$ reported this is 'very effective', while only $6 \%$ indicated 'extremely effective'. 
For data point six, $16 \%$ of the respondents reported that their organisations do not rely on internal audit for effective monitoring of controls. Where organisations do rely on internal audit, only $3 \%$ perceive this as 'not effective', and more than half, $61 \%$, reported 'effective', while $16 \%$ stated 'very effective' and $3 \%$ felt this is 'extremely effective'.

For data point seven, $10 \%$ of respondents stated their organisations do not rely on exception reports to monitor controls. Where organisations do rely on exception reports, $10 \%$ indicated this is 'not effective', more than half, $61 \%$, reported this as 'effective', $16 \%$ 'very effective' and only $3 \%$ 'extremely effective'.

In data point eight, it was found that $10 \%$ of respondents do not rely on reports generated by operating personnel to monitor controls. When organisations do rely on such reports, $16 \%$ of respondents perceive this as 'not effective'; more than half, $58 \%$, as 'effective', $13 \%$ chose 'very effective' and only $3 \%$ indicated this as 'extremely effective'.

\subsection{Descriptive statistics for summated scores}

TABLE 5 summarises the descriptive statistics for the summated scores. The mean score, among other measures, was calculated to determine the average number of participants in each of the response scales. All the sample scores fall into the neutral interval, between 2.6 and 3.4 , indicating that, for each control element, participants perceive it to be 'effective' in increasing (improving) the effectiveness of the internal control system.

TABLE 5: Descriptive statistics of summated scores for each of the components relevant to the study

\begin{tabular}{lcccc}
\hline & Risk assessment & $\begin{array}{c}\text { Information \& } \\
\text { communication }\end{array}$ & Monitoring & Control activities \\
\hline$*_{n}$ & 31 & 31 & 31 & 31 \\
Mean & 3.16 & 3.04 & 2.81 & 3.04 \\
\hline
\end{tabular}

Source: Statistical analysis

A summated mean score of 3.16 for 'risk assessment', 3.04 'Information and communication', 2.81 'Monitoring' and 3.04 'control activities' was obtained, which falls within the neutral (effective) zone, indicating that these components, with all of their specific control characteristics, are a contributing factor to the improvement of internal control systems if implemented in organisations.

\section{CONCLUSION AND RECOMMENDATIONS}

The primary objective of this study was to investigate how internal auditors perceive the importance and effect of the various COSO framework control elements on the effectiveness of internal control systems of their organisations. This article focuses only on the control components as outlined in the research question. In response to the research question and objective, TABLE 5 indicated that a mean score of 3.16 (risk assessment), 3.04 (Information and communication), 2.81 (Monitoring) and 3.04 (control activities) was obtained for all participants, meaning that internal auditors perceive the control elements as prescribed in 
these components of the COSO framework to be a contributing factor in increasing the effectiveness of internal control systems, if implemented.

Those charged with the ultimate responsibility for governance, risk and control should attempt to implement and maintain control elements as outlined in the COSO framework, especially those regarded as 'effective' as indicated by this study (refer to TABLES 1, 2, 3 and 4). As stated by Quellet (2010), senior management, such as the CEO and CFO, should continuously set the "tone at the top" as being positive towards the system of internal control. Senior management delegates some of its responsibility and authority to middle and lower management, and strict monitoring of such activities is therefore recommended. This task can be done by internal auditors, as they can independently monitor activities (providing assurance) on behalf of the board of directors and the audit committee (COSO, 2009; Cathcart \& Kapoor, 2010).

A summated mean score of 2.81 was obtained for the monitoring component of internal control, which falls within the neutral zone. Although this component is scored in the neutral zone (effective), it is clear that when compared with the summated scores of the other control components, it is rated as the lowest, and internal auditors thus do not perceive monitoring activities as the highest contributing factor to the effectiveness of internal control systems. This could contribute to other control components not serving their intended role, as the monitoring component serves, among other functions, to check whether other components are working as intended (Jackson et al., 2012). Monitoring, to a large extent, is the responsibility of management. A lack of execution of this component could be detrimental to the internal control system. By default, the elimination of the monitoring component, and/or an inadequate one, will jeopardise the integration of the control components. The monitoring component serves as an important overarching control and thus monitors/oversees the other components (Spencer Pickett, 2005; COS0, 2009; Jackson et al., 2012). A possibility thus exists that this could lead to other components becoming less effective over time if they are not frequently monitored. This conclusion is consistent with COSOs Guidance on monitoring internal control systems report, where the monitoring component is considered to be under-utilised by management in its assessment of internal control (COSO, 2009). These components are integrated, one depending on the other, together working towards an effective internal control system (Spencer Pickett, 2005). It is therefore imperative that management monitors implemented controls to determine whether they are functioning as intended. Internal auditors should serve as a monitoring tool for management.

This article concludes that the control characteristics outlined in the COSO framework for the risk assessment, information and communication, control activities and monitoring components of internal control do contribute to an improvement in the effectiveness of internal control.

\section{LIST OF REFERENCES}

Adams, M.B. (1994). Agency theory and the Internal Audit. Managerial Auditing Journal, 9(8), pp. 812 .

Agbejule, A. \& Jokipii, A. (2009). Strategy, control activities, monitoring and effectiveness. Managerial Auditing Journal, 24(6), pp. 500-522.

Aghili, S. (2010). Organizational risk management. Internal Auditor, 67(3), p. 23. 
American Institute of Certified Public Accountants (AICPA). (2005). Internal control: A tool for the audit committee. [Online] Available: http://www.niqca.org/documents/Internal_Control.pdf. (Accessed 4 June 2011).

Applegate, D. \& Wills, T. (1999). Struggling to incorporate the COSO recommendations into your audit process? [Online] Available: http://www.coso.org/audit_shop.htm. (Accessed 13 August 2012).

Baker, N. (2009). Getting in tune. Internal Auditor, 66(3), pp. 28-32.

Baker, N. (2010). Equipped for governance. Internal Auditor, 67 (1), pp. 28-29.

Barac, K. \& Plant, K. (2010). Do executives rely on internal auditors? The standing of the internal audit function within South African companies. IA Advisor, March, pp. 15-23.

Berk, S.N. \& Mehri, C.(2002). Slipping back to business as usual: Six months after the passage of Sarbanes-0xley. Journal of Investment Compliance, 3(3), pp. 70-75.

Bierstaker, J., Brody, R. \& Pacini, C. (2006). Accountants' perceptions regarding fraud detection and prevention methods. Manageria/ Auditing Journal, 21 (5), pp. 520-535.

Blackmore, J. (2010). Conversations on King III. In Touch, January, p. 15.

Cain, A. (2010). Risk management is a top concern. Internal Auditor, 67(3), pp. 13-15.

Cathcart, R. \& Kapoor, G. (2010). An internal audit upgrade. Internal Auditor, 67(3), pp. 49.

Coetzee, P., du Bruyn, R., Fourie, H. \& Plant, K. (2010). Internal Auditing: An Introduction, $2^{\text {nd }}$ ed. South Africa: LexisNexis.

Committee of Sponsoring Organizations of the Treadway Commission (COSO). (1994). Internal control - integrated framework. [Online] Available:

http://www.cpa2biz.com/media/DownloadableProducts/990012PDF.zip. (Accessed 4 June 2011).

Committee of Sponsoring Organizations of the Treadway Commission (COSO). (2009). Guidance on monitoring internal control systems. [Online] Available:

http://www.coso.org/documents/COSO_Guidance_On_Monitoring_Intro_onlinel.pdf.(Accessed l August 2012).

Committee of Sponsoring Organizations of the Treadway Commission (COSO). (2010). Board risk oversight: a progress report. [On-line] Available: http://www.coso.org/documents/Board-RiskOversight-Survey-COSO-Protiviti_000.pdf. (Accessed 4 June 2011).

D’Aquila, J.M. (1998). Is the control environment related to financial reporting decisions? Managerial Auditing Journal, 13(8), pp. 472-478.

Davis, S. \& Lukomnik, J. (2010). Enabling good governance. Interna/ Auditor, 67(2), pp. 28-29.

Gleim, I.N. (2009). CIA Review Part II: Conducting the Internal Audit Engagement. Florida: Gleim Publications.

HassabElnaby, H.R., Said, A. \& Wolfe, G. (2007). Audit Committees Oversight Responsibilities Post Sarbanes-0xley Act. American Journal of Business, 22(2), pp. 19-32.

Hemraj, M. B. (2004). Preventing corporate scandals. Journal of Financial Crime, 11(3), pp. 268-276.

Herremans, I.M. (1997). Integrating internal control in MBA programmes using the COSO and CoCo models. Managerial Auditing Journal, 12(2), pp. 60-66.

Hillison, W., Pacini, C. \& Sinason, D. (1999). The internal auditor as fraud-buster. Managerial Auditing Journal, 14(7), pp. 351-363. 
Holtfreter, K. (2005). Fraud in US organizations: An examination of control mechanisms. Journal of Financial Crime, 12(1), pp. 88-95.

Institute of Directors in Southern Africa (IOD). (2009). King report on governance for South Africa. Johannesburg, South Africa: Institute of Directors.

Institute of Internal Auditors (IIA). (2005). Practical considerations regarding internal auditing expressing an opinion on internal control. [Online] Available:

http://www.iia.nl/Sitefiles/PDF/Internal_Audit_Opinions_06-10-2005_FINAL_Is.pdf. (Accessed 2 June 2011).

Institute of Internal Auditors (IIA). (2009). International standards for the professional practice of internal auditing. Altamonte Springs, FL: IIARF.

Institute of Internal Auditors (IIA). (2010a). Practice advisory 2060-1: reporting to board and senior management. [Online] Available:

http://som.csudh.edu/depts/adjunct/mabohebeish/ACC\%20336/PA\%20ADVISORY/Practice_Advisor y_2060-1.pdf. (Accessed 2 June 2011).

Institute of Internal Auditors (IIA). (2010b). What is the appropriate relationship between the internal audit activity and the audit committee? [Online] Available:

http://www.theiia.org/theiia/about-the-profession/internal-audit-faqs/?i=1082. (Accessed 4 June 2011).

International Federation of Accountants (IFAC). (2006). Internal controls-a review of current developments. [Online] Available:

http://www.ifac.org/sites/default/files/publications/files/internal-controls-a-revie.pdf. (Accessed 9 January 2013).

Jackson, R.D.C. \& Stent, W.J. (2012). Auditing notes for South African students, $8^{\text {th }}$ ed. South Africa: LexisNexis.

KPMG. (2010). The audit committee journey: Adapting to uncertainty, focusing on transparency. 2010 public company audit committee member survey. [Online] Available:

http://www.kpmginstitutes.com/aci/insights/2010/pdf/aci-nacd-survey-2010.pdf. (Accessed 4 June 2011).

Laerd Dissertation. (2012). Snowbal/ sampling. [Online] Available:

http://dissertation.laerd.com/snowball-sampling.php. (Accessed 5 February 2012).

Losby, J \& Wetmore, A. (2012). CDC coffee break: Using likert scales in evaluation survey work.

[Online] Available: http://www.cdc.gov/dhdsp/pubs/docs/CB_February_14_2012.pdf. (Accessed 5 February 2012).

Moeller, R.R. (2007). COSO Enterprise Risk Management: Understanding the new integrated ERM framework. Toronto, Ontario: Wiley.

Moyes, G.D., Lin, P., Landry, R.M. \& Vicdan, H. ( 2006). Internal auditors' perceptions of the effectiveness of red flags to detect fraudulent financial reporting. [Online] Available: http://ssrn.com/abstract=961457. (Accessed 2 February 2011).

Petra, S.T. \& Loukatos, G. (2009). The Sarbanes-0xley Act of 2002: A five-year retrospective. Corporate Governance, 9(2), pp. 120-132.

Philmore, A. \& Howard, M. (2005). An exploratory study of auditor's responsibility for fraud detection in Barbados. Managerial Auditing Journal, 20(3), pp. 284-303.

Quellet, N. (2010). The political realm of internal auditing. Interna/ Auditor, 67(3), p. 41. 
Rezaee, Z. (1995). What the COSO report means for internal auditors. Managerial Auditing Journal, 10(6), pp. 5-9.

Rezaee, Z. (2010). The importance of internal audit opinions. Internal Auditor, 67(2), pp. 47-50.

Sawyer, L.B., Dittenhofer, M.A. \& Scheiner, J.H. (2003). Sawyer's internal auditing: The practice of modern internal auditing, $5^{\text {th }}$ ed. Altemonte Springs, FL: The Institute of Internal Auditors.

Skinner, D. \& Spira, L.F. (2003). Trust and control: A symbiotic relationship. The International Journal of Business in Society, 3(4), pp. 28-35.

Sobel, P. (2010). Is everyone anticipating risk? Internal Auditor, 67(1), p. 59.

Spencer Pickett, K.H. (2005). The essential handbook of internal auditing. Chichester, UK: Wiley and Sons.

Steffee, S. (2010). Risky business. Internal Auditor, 67(3), p. 19.

Van Wyk, A. (2010). Internal financial controls: A recurring priority in King III report. IA Advisor, March, p. 7.

Vanasco, R.R., Skousen, C.R. and Verschoor, C.C. (1995). Reporting on the entity's control structure: An international perspective. Managerial Auditing Journal, 10(6), pp. 17-48.

Vanek, C. (2012). Likert scale - What is it? When to use it? How to analyze it? [Online] Available: http://www.surveygizmo.com/survey-blog/likert-scale-what-is-it-how-to-analyze-it-and-whento-use-it/. (Accessed 5 February 2012). 


\section{Annexure A}

The following statements are based on the interrelated components of an internal control structure. Using the indicated response scale, please indicate your perception on how effective each component is in contributing to improving the effectiveness of the internal control structure at your organization. Choosing scales 2-5 also implies implementation of the procedure or control at the organization.

For each statement, please indicate with an $X$ the most applicable option for your organization. Use the following scale:

$1=$ Not true, 2 = Not effective, 3 = Effective, 4 = Very effective, 5 Extremely effective.

\begin{tabular}{|c|c|c|c|c|c|c|}
\hline 1 & \multicolumn{6}{|l|}{ RISK ASSESSMENT } \\
\hline 1.1 & The organization considers risks from external sources & 1 & 2 & 3 & 4 & 5 \\
\hline 1.2 & The organization considers risks from internal sources & 1 & 2 & 3 & 4 & 5 \\
\hline 1.3 & $\begin{array}{l}\text { The risk of a misstatement of the financial statements is } \\
\text { considered, and steps are taken to mitigate that risk }\end{array}$ & 1 & 2 & 3 & 4 & 5 \\
\hline 1.4 & $\begin{array}{l}\text { The risks associated with foreign/offshore operations are } \\
\text { considered }\end{array}$ & 1 & 2 & 3 & 4 & 5 \\
\hline 1.5 & Management estimates the significance of risk & 1 & 2 & 3 & 4 & 5 \\
\hline 1.6 & Management assesses the likelihood of risk occurring & 1 & 2 & 3 & 4 & 5 \\
\hline 1.7 & Management assesses the impact of risk occurring & 1 & 2 & 3 & 4 & 5 \\
\hline 1.8 & Management takes necessary action to manage risks identified & 1 & 2 & 3 & 4 & 5 \\
\hline 2 & \multicolumn{6}{|l|}{ INFORMATION AND COMMUNICATION } \\
\hline 2.1 & $\begin{array}{l}\text { A process is in place to collect information from external sources } \\
\text { that could have an impact on the organization and the financial } \\
\text { reporting process }\end{array}$ & 1 & 2 & 3 & 4 & 5 \\
\hline 2.2 & $\begin{array}{l}\text { Milestones to achieve financial reporting objectives are } \\
\text { monitored to ensure that timing deadlines are met }\end{array}$ & 1 & 2 & 3 & 4 & 5 \\
\hline 2.3 & $\begin{array}{l}\text { Necessary operational and financial information is } \\
\text { communicated to the right people in the organization on a timely } \\
\text { basis }\end{array}$ & 1 & 2 & 3 & 4 & 5 \\
\hline 2.4 & $\begin{array}{l}\text { Necessary operational information is communicated to the right } \\
\text { people in the organization in a format that facilitates its use }\end{array}$ & 1 & 2 & 3 & 4 & 5 \\
\hline 2.5 & $\begin{array}{l}\text { Necessary financial information is communicated to the right } \\
\text { people in the organization in a format that facilitates its use }\end{array}$ & 1 & 2 & 3 & 4 & 5 \\
\hline 2.6 & $\begin{array}{l}\text { A process is in place to respond to new information needs in the } \\
\text { organization on a timely basis }\end{array}$ & 1 & 2 & 3 & 4 & 5 \\
\hline 2.7 & $\begin{array}{l}\text { There is a process in place to collect and document complaints } \\
\text { to analyze, determine cause, and eliminate a problem from } \\
\text { recurring in the future }\end{array}$ & 1 & 2 & 3 & 4 & 5 \\
\hline
\end{tabular}




\begin{tabular}{|c|c|c|c|c|c|c|}
\hline 2.8 & $\begin{array}{l}\text { There is a process in place to collect and document errors to } \\
\text { analyze, determine cause, and eliminate a problem from } \\
\text { recurring in the future }\end{array}$ & 1 & 2 & 3 & 4 & 5 \\
\hline 2.9 & $\begin{array}{l}\text { A process is established and communicated to stakeholders } \\
\text { about how to communicate suspected instances of wrongdoing } \\
\text { by the organization }\end{array}$ & 1 & 2 & 3 & 4 & 5 \\
\hline 2.10 & $\begin{array}{l}\text { The accounting system consists of different classes of } \\
\text { transactions }\end{array}$ & 1 & 2 & 3 & 4 & 5 \\
\hline 2.11 & The accounting system ensures completeness of records & 1 & 2 & 3 & 4 & 5 \\
\hline 2.12 & The accounting system ensures accuracy of records & 1 & 2 & 3 & 4 & 5 \\
\hline 2.13 & The accounting system avoids duplicate recording & 1 & 2 & 3 & 4 & 5 \\
\hline 3 & MONITORING & & & & & \\
\hline 3.1 & $\begin{array}{l}\text { Personnel are required to sign off, indicating their performance } \\
\text { of critical control activities such as performing reconciliations }\end{array}$ & 1 & 2 & 3 & 4 & 5 \\
\hline 3.2 & $\begin{array}{l}\text { Employees understand their obligation to communicate } \\
\text { observed weaknesses in design with the internal control } \\
\text { structure of the organization to the appropriate supervisory } \\
\text { personnel }\end{array}$ & 1 & 2 & 3 & 4 & 5 \\
\hline 3.3 & $\begin{array}{l}\text { Employees understand their obligation to communicate } \\
\text { observed weaknesses in compliance with the internal control } \\
\text { structure of the organization to the appropriate management } \\
\text { personnel }\end{array}$ & 1 & 2 & 3 & 4 & 5 \\
\hline 3.4 & $\begin{array}{l}\text { The organization relies on customer complaints to identify } \\
\text { certain control weaknesses }\end{array}$ & 1 & 2 & 3 & 4 & 5 \\
\hline 3.5 & $\begin{array}{l}\text { There is follow-up on recommendations from the internal } \\
\text { auditors for improvements to the internal control system }\end{array}$ & 1 & 2 & 3 & 4 & 5 \\
\hline 3.6 & $\begin{array}{l}\text { The organization relies on the internal audit department for } \\
\text { effective monitoring of controls }\end{array}$ & 1 & 2 & 3 & 4 & 5 \\
\hline 3.7 & $\begin{array}{l}\text { The organization relies on exception reports to monitor } \\
\text { effectiveness of controls }\end{array}$ & 1 & 2 & 3 & 4 & 5 \\
\hline 3.8 & $\begin{array}{l}\text { The organization relies on operating personnel generated reports } \\
\text { to monitor controls }\end{array}$ & 1 & 2 & 3 & 4 & 5 \\
\hline 4 & CONTROL ACTIVITIES & & & & & \\
\hline 4.1 & $\begin{array}{l}\text { The organization has a process in place to ensure that controls } \\
\text { as described in policy and procedure manuals are applied as } \\
\text { they are meant to be applied }\end{array}$ & 1 & 2 & 3 & 4 & 5 \\
\hline 4.2 & $\begin{array}{l}\text { Policy and procedure manuals document all important policies } \\
\text { and procedures }\end{array}$ & 1 & 2 & 3 & 4 & 5 \\
\hline 4.3 & $\begin{array}{l}\text { Policies and procedures are reviewed and updated on a regular } \\
\text { basis }\end{array}$ & 1 & 2 & 3 & 4 & 5 \\
\hline
\end{tabular}


THE IMPACT OF COSO CONTROL COMPONENTS ON INTERNAL CONTROL EFFECTIVENESS

\begin{tabular}{|l|l|l|l|l|l|l|}
\hline 4.4 & Supervisory personnel review the functioning of controls & 1 & 2 & 3 & 4 & 5 \\
\hline 4.5 & $\begin{array}{l}\text { Timely and appropriate follow-up action is taken on exception } \\
\text { reports }\end{array}$ & 1 & 2 & 3 & 4 & 5 \\
\hline 4.6 & Custody over assets is separate from accounting & 1 & 2 & 3 & 4 & 5 \\
\hline 4.7 & $\begin{array}{l}\text { Operational responsibility and record-keeping responsibility are } \\
\text { separated }\end{array}$ & 1 & 2 & 3 & 4 & 5 \\
\hline 4.8 & Physical control over assets exists & 1 & 2 & 3 & 4 & 5 \\
\hline 4.9 & There are independent checks on performance & 1 & 2 & 3 & 4 & 5 \\
\hline
\end{tabular}

Source: Research instrument 
Fourie \& Ackermann 